\title{
The Relationship between Supply Chain Integration and Performance of Agricultural Listed Companies
}

\author{
Jianhua YANG \\ College of Business Administration \\ Shandong Technology and Business University \\ Yantai, China \\ e-mail: Billyang1973@sina.com
}

\author{
Fangfang REN \\ College of Business Administration \\ Shandong Technology and Business University \\ Yantai, China \\ e-mail:798055735@qq.com
}

\begin{abstract}
Based on transaction cost theory, information processing theory and resource dependency theory, this paper selects the data of agricultural listed companies from 2012 to 2015 as the research object to analyses the effect of supplier integration and customer integration on agricultural listed companies' performance respectively. The empirical results show that supplier integration has a positive effect on market performance, while customer integration has a negative effect on financial performance. It shows that agricultural listed companies lack of customer management; therefore, agricultural listed companies should establish cooperation relationship with customers to improve the comprehensive competitiveness through the implementation of supply chain management.
\end{abstract}

Keywords-supply chain integration; agricultural listed companies; market performance; financial performance

\section{INTRODUCTION}

After the mid 1990s, the rapid development of science and technology and the acceleration of globalization process have led to the oversupply of agricultural products in China. The customers' high and changing demand for agricultural products have intensified the fierce competition in the market. The uncertainty degree of external environment is getting higher and higher, making the management from agricultural producers to agricultural integrated enterprise is more and more complex. So many enterprises adopted non-core business outsourcing to improve the market competitiveness. Due to the long-term constraints of the old system, there are many problems and contradictions in the development of agriculture during the past decades, such as the low organization degree of farmers, the backward professional production and the difficulties docking with grand market. These problems have seriously affected the process of transition from agriculture to market economy. In this situation, agricultural producers and related enterprises have to consider establishing a certain supply chain management to coordinate and solve these problems.

Nowadays, the processing industry of agricultural products is increasingly widespread into China's agriculture. It is the leading enterprise of agricultural industrialization, which has led the deepening reform of China's agriculture. Therefore, building a high efficiency agricultural products supply chain with the core of agricultural leading enterprises is the key to maintaining agricultural value-added, and also an effective way to maintain sustainable market competitiveness. The key of the successful supply chain management is to promote information and process integration among the members in the supply chain [1]. Supply chain integration is regarded as an important strategic entrance to create value and enhance competitive advantage [2]. In practice, many companies have benefited from supply chain integration, such as HP, Dell, etc.

For the relationship between supply chain integration and enterprise performance, many scholars at home and abroad have conducted theoretical and empirical research from different angles. Chen et al established a two stage supply chain model of a single retailer and a single manufacturer, the theoretical research showed that customer integration can reduce the uncertainty caused by the bullwhip effect [3]. Swink et al made a study on the manufacturing industry and found that supplier integration had a significant effect on business performance, and customer integration had no significant effect on business performance [4]. Kim carried on a empirical analysis and found that supplier integration and customer integration both have a significant effect on enterprise performance [5]. Zhao Quanwu et al used a large sample of financial and operating data to research and found that supplier integration has no relationship with the operating performance, but is has positive relationship with financial performance, customer integration is positively related to operating performance and financial performance [6]. It can be seen that many conclusions about the relationship between supply chain integration and enterprise performance are still inconsistent.

So, in the supply chain with the core of agricultural products processing enterprises, whether the integration among processing enterprises and upstream and downstream organizations can enhance the enterprises performance, such studies are less involved. Therefore, this paper divides the supply chain integration into supplier integration and customer integration to study the mechanism about supplier integration and customer integration on Enterprise Performance.

Based on the above analysis and previous studies, this paper studies the mechanism about supply chain integration on the enterprises performance as the research object of Chinese agricultural listed companies, and tests the application of supply chain management theory in 
agricultural industry, so as to provide a theoretical basis for the enterprises to develop business strategy and the government to formulate industrial policies.

\section{TheORETICAL ANALYSIS AND RESEARCH HYPOTHESIS}

From the perspective of economics theory and management theory, this paper discusses the mechanism of supply chain integration on the performance of agricultural enterprises based on transaction cost theory, resource dependence theory and information processing theory.

In "The Problem of Social Cost ", Coase argued that any information gathering and business negotiation which carried out by any different economic entity in the course of transaction would create transaction costs and these costs are called transaction costs [7]. Based on the theory of Coase's, Williamson further developed Transaction Cost Theory (TCT), which pointed out that transaction costs were affected by asset specificity, transaction uncertainty and transaction frequency [8]. Enterprises with a small number of suppliers to carry out multi-frequency transactions, on the one hand, it can establish a stable relationship with suppliers and reduce the cost of search partners. On the other hand, the long-term stable cooperation with fewer suppliers can enhance mutual trust, improve communication quality and reduce transaction risk caused by environmental uncertainty [9], ultimately, a high level of funds will realize.

At the same time, the information processing theory (IPT) believes that sufficient information communication with suppliers can get demand, ability, technology and other related information timely, that makes it easy to identify non value-added activities of enterprises and to achieve the purpose of reducing cost [10]. Supplier integration can enable suppliers to participate in the production plan, it can provide enterprises with appropriate agricultural raw materials, and ensure the continuous supply of raw materials and the quality of raw materials. Meanwhile, the supplier integration also make the enterprise not be affected by imbalance between market supply and demand for agricultural products production, thus, it ensures the timely delivery of the final product and improves the customer satisfaction. Agricultural enterprises mainly use agricultural products as raw materials for processing, and the quality of raw materials provided by suppliers will directly affect the quality of products provided for downstream customers [11]. Therefore, the stable cooperation with suppliers can meet the production needs of enterprises, improve the market share of enterprises and market performance. Thus, hypothesis is put forward:

H1: Supplier integration has a positive effect on market performance.

H2: Supplier integration has a positive effect on financial performance.

IPT believes that maintaining sufficient information communication with customers will provide a guarantee for enterprises to actively respond to the needs of individual customers, enter new markets and improve market competitiveness. Enterprises establish a stable cooperative relationship with customers can get accurate customer needs and market information; in the meantime, it can also make production and sales plans timely and improve market response speed. The full information exchange between the enterprise and the customer reduces the impact of the bullwhip effect and improves the enterprise income and satisfaction of customer. Huo believes that information sharing not only can help supply chain partners to get a fast and consistent flow of information between each other, but also can understand each other's business, so as to reduce the opportunism behavior in the transaction process ${ }^{[12]}$. Flynn B B et al conducted an empirical study to show that customer integration had a significant positive effect on operating performance ${ }^{[13]}$.

TCT believes that asset specificity increases the transaction costs of all forms of governance because of the presence of opportunism. The establishment of a cooperative relationship between enterprise and major customers means that the assets of the enterprise have certain specificity to the main customers. Based on this, customer integration will increase transaction costs of enterprises, and higher asset specificity of enterprises will increase the financial risk, thus the integration of customers hinders the improvement of enterprise performance. However, according to the resource dependence theory (RDT), the enterprise can survive and develop on the basis of the external environment. The control and seize for the key resources of the enterprise can make the enterprise obtain the heterogeneous resources and the unique competitive advantage ${ }^{[14]}$; At the same time, resource dependence can make both sides form a community interest and enhance the performance of both sides ${ }^{[15]}$. Thus, hypothesis is put forward:

H3: Customer integration has a positive effect on market performance.

H4a: Customer integration has a positive effect on financial performance.

H4b: Customer integration has a negative effect on financial performance.

\section{RESEARCH DESIGN}

\section{A. Sample Selection and Data Sources}

According to the research needs, this paper selects the agricultural enterprises which are in line with the 'Listed company profession classification direction' as the research sample, there are mainly agricultural enterprises, animal husbandry enterprises, fishery enterprises and the processing enterprises that directly using agricultural products as raw materials. On this basis to do the following: (1) reject companies that have made significant changes in their principal operations, (2) reject companies that sample data are missing, (3) reject ST, ST * companies that listed after 2012 , finally, we get the data of 95 companies as samples.

The data of supplier integration and customer integration are collected from the annual report of listed companies, other data are from the CSMAR database, we eventually get data of 2012 to 2015 and use SPSS.19.0 for processing. 


\section{B. Definition of Primary Variables}

1) Dependent variables: financial performance and market performance.

This paper chooses the rate of return on common stockholders' equity (ROE) to measure financial performance, and chooses the sales gross profit ratio (GPR) to measure market performance.

2) Explanatory variables: supplier integration (SI) and customer integration (CI).

Since 2007, China Securities Regulatory Commission encourage listed companies to disclose "the top five suppliers total purchase ratio" and "the top five customers total sales ratio" in the annual report publicly, and these two pieces of information are the most relevant with SCI. Zhuang Bo Chao et al who used the top five supply and sales ratio on behalf of the enterprise procurement concentration and sales concentration, Therefore, this paper draws lessons from previous practice, we use the top five supply and sales ratio to measure the degree of supplier integration (SI) and customer integration (CI).

\section{3) Control variable}

In order to avoid the impact of individual differences on the research, this paper control the following variables refers to the general practice: (1) enterprise scale, the enterprise scale is represented by the logarithm of the total assets at the end of the enterprise. (2) financial leverage, the financial leverage is represented by the asset-liability ratio of the enterprise. (3) enterprise age, the enterprise age is represented by the length of time since the company has been listed to the present. The relevant variables are defined in Table 1 below.

TABLE I. DEFINITION OF PRIMARY VARIABLES

\begin{tabular}{|c|c|c|}
\hline $\begin{array}{l}\text { Variable } \\
\text { Name }\end{array}$ & $\begin{array}{l}\text { Variable } \\
\text { Code }\end{array}$ & Variable Definition \\
\hline $\begin{array}{l}\text { Financial } \\
\text { Performance }\end{array}$ & ROE & $\begin{array}{c}\text { Net Margin/ Average Shareholders' } \\
\text { Equity }\end{array}$ \\
\hline $\begin{array}{l}\text { Market } \\
\text { performance }\end{array}$ & GPR & $\begin{array}{l}\text { (Operating Income }- \text { Operating } \\
\text { Cost) / Operating Income } * 100\end{array}$ \\
\hline $\begin{array}{l}\text { Customer } \\
\text { Integration }\end{array}$ & CI & The top five customers total sales ratio \\
\hline $\begin{array}{l}\text { Supplier } \\
\text { Integration }\end{array}$ & SCI & $\begin{array}{l}\text { The top five suppliers total purchase } \\
\text { ratio }\end{array}$ \\
\hline $\begin{array}{l}\text { Enterprise } \\
\text { Scale }\end{array}$ & Size & Logarithm of total assets \\
\hline $\begin{array}{l}\text { Financial } \\
\text { Leverage }\end{array}$ & Lev & $\begin{array}{l}\text { The final total liabilities/final total } \\
\text { assets } * 100\end{array}$ \\
\hline $\begin{array}{l}\text { Enterprise } \\
\text { Age }\end{array}$ & Age & $\begin{array}{l}\text { The number of years from the year of } \\
\text { establish to } t\end{array}$ \\
\hline
\end{tabular}

\section{Model Specification}

The following two models are used to verify the effect of supply chain integration on the performance of agricultural enterprises. Between them, represents the market performance and financial performance of the first $i$ company in the period $\mathrm{t}$.

Performance $_{i t}=\alpha_{0}+\alpha_{1} C I+\alpha_{2} L e v+\alpha_{3}$ Size $+\alpha_{4}$ Age $+\varepsilon_{i t}$

Performance $_{i t}=\alpha_{0}+\alpha_{1} S I+\alpha_{2} L e v+\alpha_{3}$ Size $+\alpha_{4}$ Age $+\varepsilon_{i t}$

\section{EMPIRICAL ANALYSIS}

TABLE II. REGRESSION RESULTS OF THE MODEL

\begin{tabular}{|l|l|l|l|l|}
\hline & \multicolumn{1}{|c|}{$(\mathbf{1})$} & \multicolumn{1}{|c|}{$(\mathbf{2})$} & \multicolumn{1}{c|}{$(\mathbf{3})$} & \multicolumn{1}{c|}{} \\
\hline & GPR & ROE & GPR & ROE \\
\hline SI & $0.197 * * *$ & 0.01 & & \\
\hline CI & & & 0.023 & $-0.094^{* *}$ \\
\hline SIZE & $0.370^{* *}$ & $0.428 * * *$ & $0.342^{* * *}$ & $0.399 * * *$ \\
\hline AGE & 0.066 & 0.026 & $0.085^{*}$ & 0.033 \\
\hline LEV & $-0.356 * *$ & $-0.303 * *$ & $-0.387^{* *}$ & $-0.311^{* *}$ \\
\hline
\end{tabular}

Table 2 shows the regression results of the model. The regression result (1) shows that $\mathrm{SI}$ has a significant positive effect on GPR, it indicates that the higher degree of supplier integration, the higher gross margin of agricultural enterprises, the higher market performance, namely, SI can significantly improve the market performance of listed companies, so $\mathrm{H} 1$ is supported. The regression result (2) shows that SI positively correlates with ROE, but the regression coefficient between the two is not significant, So $\mathrm{H} 2$ is not supported. The reason may be that the agricultural enterprises are too dependent on key suppliers after establish cooperative relations with them, therefore, it has no competitive advantage in bargaining with suppliers, and also weaken the profits of enterprises in the process of supplier integration. So, SI has no significant effect on financial performance. The regression result (3) shows that CI positively correlates with GPR, but the regression coefficient between the two is not significant, So H3 is not supported. The regression result (4) shows that CI has a negative effect on ROE, it indicates that the higher degree of customer integration is not conducive to improve the financial performance of enterprises. This empirical result is similar to the conclusion of Tang Yuejun's, it shows that there is no linear relationship between enterprise customer integration and financial performance, but exists an optimal integration degree where has a positive effect on financial performance, and the degree of integration is too high or too low is not conducive to improve financial performance of agricultural enterprises. If the degree of customer integration is too high, agricultural enterprise has a higher specific asset investment for customers. Once have the customer opportunistic behavior, it will inevitably lead to enterprise financial constraints while increase the financial risk of enterprises. So as to we support the hypothesis H4b and deny hypothesis $\mathrm{H} 4 \mathrm{a}$.

It can also be obtained from table 2: The SIZE of control variables has a significant positive effect on GINCMRT and $\mathrm{ROE}$, it indicates that the scale of enterprise contributes to the improvement of enterprise performance. However, LEV has a significant negative impact on GINCMRT and ROE, it indicates that the levels of enterprise debt will lead to a decline of enterprise performance. All these results are consistent with the conclusion of the existing literature.

\section{RESEARCH CONCLUSIONS AND REVELATION}

Based on the data of agricultural enterprises from 2012 to 2015 , this paper researches the effect of supplier integration 
and customer integration on agricultural listed companies' performance respectively. The research results of this paper are as follows: supplier integration can improve the market competitiveness of enterprises and enhance the market performance, but for the aspect of customer integration, the higher degree of customer integration, the more unfavorable for enterprises to improve financial performance. The reasons for this conclusion are as follows: firstly, compared with other industries, agricultural industry is characterized by strict requirements for raw materials and the prices of products produced are very volatile, so agricultural enterprises are limited by many factors in the implementation of supply chain integration; Secondly, the market environment of our country is different from that of foreign countries, the phenomenon about government intervention and human relations is serious, which has seriously affected the cooperation relationship between enterprises and suppliers and customers. Therefore, agricultural enterprises can't copy the implementation method of other industries when carry out the supply chain integration, but need to take into account the market environment and the particularity of its industry, and then through the implementation of supply chain management to improve market competitiveness and financial performance.

The implications of this paper are listed as follows: firstly, the disclosure of information about the supply chain is valuable, and the listed companies should be encouraged to disclose more information about the suppliers and customers; Secondly, supply chain integration is an effective strategic management method, it is necessary to vigorously advocate agricultural enterprises combining with the characteristics of industry to implement supply chain management, so as to improve the overall competitiveness of China's agricultural enterprises.

\section{REFERENCES}

[1] Douglas M. Lambert and Martha C. Cooper, Issues in Supply Chain Management, 1st ed. Industrial Marketing Management, 2000, pp. 6583.

[2] Chee Yew Wong, Sakun Boon-Itt and Christina W. Y. Wong, The contingency effects of environmental uncertainty on the relationship between supply chain integration and operational performance, 6th ed. Journal of Operations Management, 2011, pp. 604-615.
[3] Frank Chen and David Simchi-Levi, Quantifying the Bullwhip Effect in a Simple Supply Chain: The Impact of Forecasting, Lead Times, and Information, 3rdt ed. Management Science, 1999, pp. 436-443.

[4] Morgan Swink, Ram Narasimhan and Cynthia Wang, Managing beyond the factory walls: Effects of four types of strategic integration on manufacturing plant performance, 1st ed. Journal of Operations Management, 2007, pp. 148-164.

[5] Dong Young Kim, Relationship between supply chain integration and performance, 1st ed. Operations Management Research, 2013, pp. 74 90.

[6] Quan-Wu ZHAO, Qing WANG and Ya-Feng HUANG, An empirical study on supply chain partnership and firm performance in manufacturing industry, 11th ed. East China Economic Management, 2010, pp. $128-131$.

[7] Hai-Ping WANG, Research on the theoretical framework of supply chain management, 1st ed., jan. Economic Problems, 2007, pp. 16-18.

[8] Williamson OE. The economic institution of capitalism [M].NY:Free Press. 1985.

[9] Todd H. Chiles and John F. Mcmackin, INTEGRATING VARIABLE RISK PREFERENCES. TRUST. AND TRANSACTION COST ECONOMICS, 1st ed. Academy of Management Review, 1996, pp. 73-99.

[10] Beamon B M, International Journal of Operations \& Production Management, 3rd ed. International Journal of Operations \& Production Management, 2007, pp. 275-292.

[11] Cornelia Droge, Jayanth Jayaram and Shawnee K. Vickery, The effects of internal versus external integration practices on time-based performance and overall firm performance, 6th ed. Journal of Operations Management, 2004, pp. 557-573.

[12] Baofeng Huo, An exploratory study of power, relationship commitment, supply chain integration and performance. 2007 .

[13] Barbara B. Flynn, Baofeng Huo and Xiande Zhao, The impact of supply chain integration on performance: A contingency and configuration approach, 1st ed. Journal of Operations Management, 2010, pp. 58-71.

[14] Mao-Jian YU and Yuan-Xin SUN, Specific investment, governance mechanism and corporate performance -- Empirical Evidence from Listed Companies in manufacturing industry, 1st ed. Journal of Industrial, 2014, pp. 39-47.

[15] Jeffrey H. Dyer and Harbir Singh, The Relational View: Cooperative Strategy and Sources of Interorganizational Competitive Advantage, 4th ed. The Academy of Management Review , 1998, pp. 660-679.

[16] Bo-Chao ZHUANG, Shi-Qing YU and Hong ZHANG, Supply chain concentration, capital operation and operating performance: An Empirical Study Based on Chinese Manufacturing Listed Companies, 3rd ed. Soft science, 2015, pp. 9-14.

[17] Yue-Jun TANG, Suppliers and dealer's bargaining power and firm performance: evidence from Chinese manufacturing listed companies from 2005 to 2007, 1st ed. Chinese industrial economy, 2009, pp. 6776. 